\title{
Phytochemistry and Biological Properties of Burnet Weed (Sanguisorba spp.): A Review
}

\author{
Anestis KARKANIS ${ }^{1}$, Evangelos VELLIOS ${ }^{1}$, Thomas THOMAIDIS ${ }^{2}$, \\ Dimitrios BILALIS ${ }^{3 *}$, Aspasia EFTHIMIADOU ${ }^{4}$, Ilias TRAVLOS ${ }^{3}$ \\ ${ }^{1}$ University of Thessaly, Department of Agriculture Crop Production and Rural Environment, Nea Ionia, Magnesia, \\ Greece; anekark80@yahoo.gr; vvellios@agr.uth.gr \\ ${ }^{2}$ University of Thessaly, LiaisonOffice, Greece; thomaidistv@gmail.com \\ ${ }^{3}$ Agricultural University of Athens, Department of Crop Science, Laboratory of Crop Production, Athens, \\ Greece; bilalisdimitrios@yahoo.gr ("correspondingauthor); htravlos@yahoo.gr \\ ${ }^{4}$ New York College, Dean of Postgraduates, Athens, Greece; sissyefthimiadou@yahoo.gr
}

\begin{abstract}
Great burnet (Sanguisorba officinalis L.) and small burnet (Sansguisorba minor Scop.) are edible, perennial weeds widely distributed in the world. These are the most widespread Sanguisorba species. The bioactive components of Sanguisorba plants include phenolics (phenolic acids, flavonoids and neolignans) and terpenoids. Large potential exists to use burnets as medicinal plants. Sanguisorba species are known to show anticancer properties, antioxidative, antimicrobial and antiviral activities. Also, Sanguisorba extracts show anti-Alzheimer and antiinflammatory properties. Small burnet extracts could also be a useful alternative to synthetic fungicides for crop production. This review focuses on biological activities of Sanguisorba extracts and emphasizing their potential applications in pharmaceutical areas.
\end{abstract}

Keywords: burnet, human health,phenolics, plant extracts, terpenoids

\section{Introduction}

Natural products are important for human health and drug discovery (Ji et al., 2009; Mondal et al., 2012). Many species of medicinal-aromatic plants are cultivated for industrial uses (i.e. colorants, dyes, biocides, pharmaceuticals), but most are still wild collected (Lubbe and Verpoorte, 2011). Burnets (Sanguisorba officinalis L. and Sanguisorba minor Scop.), as well as several other herbs (Efthimiadou et al., 2012; Karkanis et al., 2011; Xia et al., 2011), have been used extensively in traditional medicine (Cuccioloni et al., 2012; Retta et al., 2012; Yu et al., 2011).

Large potential exists to cultivate burnet as medicinal plant. Moreover, small burnet has good forage quality (Elgersma et al., 2013a). Burnet plants are very good cold tolerant. A limiting factor in burnet production is weed competition. There is a report that small burnet can tolerate bromoxynil, clethodim, clopyralid, dimethenamid-P, metribuzin, pendimethalin andquincloracherbicides (Nelson et al., 2014).The aim of this paper is to review the existing literature and explore the potential of burnet plants for medicinal properties.

\section{Botanical-morphological description}

Burnet (Sanguisorba spp.) is a member of the Rosaceaee family. Great burnet (Sanguisorba officinalis L.) and small burnet (Sansguisorba minor Scop. (synonym
Poterium sanguisorba L.)) are the most widespread Sanguisorba species. Burnets are perennial herbs widely distributed throughout Europe, Asia and other parts of the world.

Burnets plants have pinnate leaves (Fig. 1). Leaflets are in pairs placed opposite or alternative. Inflorescences appear at the end of stems. The flowers have four sepals and no petals (Sutton, 2007; Andrabi et al., 2012). The seeds are achenes. The weight of 1000 burnet seeds is $10 \mathrm{~g}$.

S. minor is a drought tolerant species (Koukoura et al., 2007). Douglas et al. (1994) reported that $S$. minor plants in the dry regime had soluble sugar levels of 1.4-1.7 times higher than those watered adequately, which suggested that plants adjusted to water depletion.

Sanguisorba plants can be propagated from seeds. Seeds of Sanguisorba spp. germinated most rapidly at 24 to $25^{\circ} \mathrm{C}$ constant temperatures, following 6 months of dry storage at $4{ }^{\circ} \mathrm{C}$. Presence or absence of light does not affect germination percentages (Holloway and Matheke, 2003).

\section{Burnets active constituents}

Burnets contains several active compounds. The active constituents of Sanguisorba plants include phenolics: phenolic acids, flavonoids (i.e. quercetin; Fig. 2), neolignans and terpenoids. Ranfa et al. (2014) reported that small burnet exhibited the highest total polyphenols $(258 \mathrm{mg} / 100 \mathrm{~g})$ content. Vanzani et al. (2011) also found that the amount of 
396
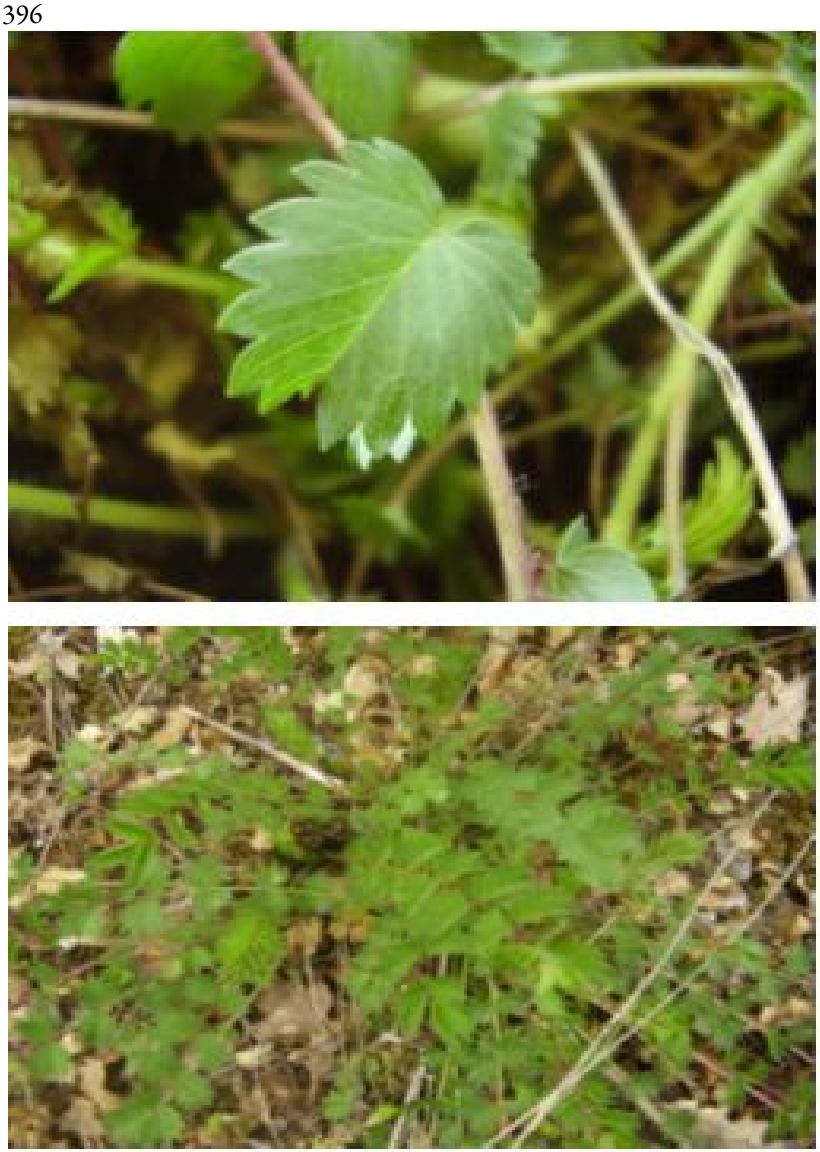

Fig. 1. Plant and leaves of small burnet (Sanguisorba minor Scop.)<smiles>O=c1c(O)c(-c2ccc(O)c(O)c2)oc2cc(O)cc(O)c12</smiles>

Fig. 2. Structure of quercetin polyphenols present in small burnet was particularly high (98.2 mmol total phenols $/ \mathrm{kg}$ ). Moreover, small burnet contains high levels of $\alpha$-tocopherol ( $85 \mathrm{mg} / \mathrm{kg}$ dry matter) and $\beta$-carotene ( $30 \mathrm{mg} / \mathrm{kg}$ dry matter; Elgersma et al., 2013b). Bioactive compounds isolated from Sanguisorba leaves and roots are listed in Tab. 1.

\section{Burnets and human health}

S. officinalis leaves can be used in salads or for various extracts or specialized preparations. Several studies have recently confirmed the anticancer properties of burnet plants (Goun et al., 2002). According to Wang et al. (2012) and Shin et al. (2012) S. officinalis inhibited the growth of breast and oral cancer. Choi et al. (2012a) also observed that extracts of $S$. officinalis could be used for treatment of prostate cancer.

Furthermore, Sanguisorba species are known to show antioxidative activities. Menkovic et al. (2007) reported that $S$. minor and $S$. officinalis extracts showed strong antioxidant activity. There was a correlation between the phenolic content and antioxidant activity. Moreover, Choi et al. (2012b) reported that ZYM-201 sodium succinate (salt form) can be used for the treatment of atherosclerosis and vascular diseases. ZYM-201 (methyl ester of a triterpenoid glycoside) is isolated from S. officinalis (Choi et al., 2006).

Burnet plants also show antiviral and antimicrobial activities. According to Bedoya et al. (2001) and Abad et al. (2000) the aqueous extracts of $S$. minor showed inhibitory effects against human immunodeficiency virus type 1 (HIV$1)$, herpes simplex virus type I (HSV-1) and vesicular stomatitis virus (VSV). Furthermore, Moreira et al. (2011) reported that the $S$. bybrida extracts showed high antibacterial activity against Staphylococcus aureus.

Moreover, Sanguisorba extracts show anti-Alzheimer activities. Sanguisorba spp. extracts inhibited the glycogen synthase kinase $3 \beta$ (Kaufmann et al., 2009). Glycogen synthase kinase 3 has been shown to play an important role in Alzheimer's disease (Anand and Singh, 2013; Kaufmann et al., 2009). Moreover, it has been reported that acetylcholinesterase enzyme inhibitors are approved for Alzheimer management (Tabet, 2006). Ferreira et al. (2006) found that $S$. minor showed the best inhibition of acetylcholinesterase enzyme. These findings indicate that Sanguisorba extracts could be used against Alzheimer's disease.

Tab. 1. Bioactive compounds isolated from burnet plants

\begin{tabular}{|c|c|c|c|}
\hline Compound & Reference & Compound & Reference \\
\hline sanguidioside A & Liu et al. (2004) & gallic acid & Ayoub (2003) \\
\hline sanguidioside B & Liu et al. (2004) & ellagic acid & Ayoub (2003) \\
\hline sanguidioside $\mathrm{C}$ & Liu et al. (2004) & quercetin-3-O-(600-galloylglucose) & Ayoub (2003) \\
\hline sanguidioside D & Liu et al. (2004) & b-glucogallin & Ayoub (2003) \\
\hline quercetin & Ayoub (2003) & quercetin-3-glucuronide & $\begin{array}{l}\text { Cuccioloni et al. } \\
\text { (2012) }\end{array}$ \\
\hline 2,3-hexahydroxydiphenol-(a/b)-glucose & Ayoub (2003) & $\begin{array}{l}\text { 1-gallory-2,3-hexahydroxydroxyediphenol-a- } \\
\text { glucose }\end{array}$ & Ayoub (2003) \\
\hline 2-(4-carboxy-3-methoxystyryl)-2 methoxysuccinic acid & Ayoub (2003) & $\begin{array}{l}\text { 4,8-dimethoxy-7-hydroxy-2-oxo-2H-1- } \\
\text { benzopyran-5,6-dicarboxylic acid }\end{array}$ & Ayoub (2003) \\
\hline $\begin{array}{l}\text { (7S,8R)-4,9,5',9'-tetrahydroxy-3,3'-dimethoxy-8-O-4'- } \\
\text { neolignan-7-O- } \alpha \text {-l-rhamnopyranoside }\end{array}$ & Hu et al. (2012) & $\begin{array}{c}\text { (7S,8R)-4,9,9'-trihydroxy-3,3',5'-trimethoxy-8-O- } \\
\text { 4'-neolignan-7-O- } \alpha-1 \text {-rhamnopyranoside }\end{array}$ & Hu et al. (2012) \\
\hline $\begin{array}{l}\text { (7S,8R)-4,7,9,9'-tetrahydroxy-3,3'-dimethoxy-8-O-4'- } \\
\text { neolignan }\end{array}$ & Hu et al. (2012) & $\begin{array}{c}\text { 3b-[(a-L-arabinopyranosyl)oxy }]-19 \mathrm{~b}-\text { hydroxyurs- } \\
\text { 12,20(30)-dien-28-oic acid }\end{array}$ & Liu et al. (2005) \\
\hline
\end{tabular}


Anti-inflammatory properties of $S$. officinalis have been the subject of several studies. Lee et al. (2010) observed that $S$. officinalis ethanol extract has therapeutic potential against bronchial asthma associated with allergic diseases. Yu et al. (2011) also found that burnet extracts can be effectively applied as a therapeutic agents and anti-inflammatory herbal medicines.

Furthermore, Chapman (2013) reported that the $S$. officinalis treatment significantly reduced hair loss and significantly reduced the telogen/anagen ratio. S. minor is also used to treat bites of the most venomous snakes in southern Europe (i.e. Bosnia and Herzegovina), such as Vipera berus and Vipera ammodytes (Redzic, 2010).

\section{Small burnet and other uses}

Small burnet extracts could be a useful alternative to synthetic fungicides in the management of postharvest fungal pathogens (Gatto et al., 2011). The authors reported that the extracts from small burnet completely inhibited in vitro spore germination of Monilnialaxa, Penicilliumdigitatum, Pencilliumitalicum and Aspergilusniger, while it significantly reduced those of Botrytis cinerea and Pencilliumexpansum. Askarne et al. (2012) also observed that the powder of Sanguisorba minor was effective against $P$. italicum. Kokubun et al. (1994) found that the root tissue of $S$. minor produced the phenolic compound 2'6'-dihydroxy-4'methoxyacetophenone as a phytoalexin after fungal inoculation with Botrytis cinerea.

Moreover, the dry powder of small burnet leaves could be used to enrich vegetable oils with low content of natural antioxidant, such as sunflower and corn oil (Romojaro et al., 2013). Finally, the addition of $S$. minor (leaves and stems) increased the content of phenolic compounds and antioxidant capacity in orange and kiwifruit juices in more than 30\% (Sanchez-Bel et al.2014).

\section{Conclusions}

Burnets are perennial herbs widely distributed throughout Europe, Asia and other parts of the world. Burnets are rich in bioactive compounds. Great burnet (Sanguisorba officinalis L.) and small burnet (Sansguisorba minor Scop.) plants show anticancer, antioxidative, antiviral and antimicrobial activities. Furthermore, Sanguisorba extracts could be used against Alzheimer's disease. Their pharmacological properties are due to the presence of phenolics and terpenoids as active constituents.

\section{References}

Abad MJ, Guerra JA, Bermejo P, Irurzun A, Carrasco L (2000). Search for antiviral activity in higher plant extracts. Phytother Res 14:604-607.

Anand P, Singh B (2013). Flavonoids as lead compounds modulating the enzyme targets in Alzheimer's disease. Med Chem Res 22(7):3061-3075.

Andrabi SM, Rehman W, Reshi ZA, Naqshi AR, Aijaz GH (2012). Sanguisorba minor Scop. (Rosaceae), a new addition to the Indian flora. Taiwan 57(4):410-412.
Askarne L, Talibi I, Boubaker H, Boudyach EH, Msanda F, Saadi B, Serghini MA, Ait Ben Aoumar A (2012). In vitro and in vivo antifungal activity of several Moroccan plants against Penicilliumitalicum, the causal agent of citrus blue mold. Crop Prot 40:53-58.

Ayoub NA (2003). Unique phenolic carboxylic acids from Sanguisorba minor. Phytochem 63:433-436.

Bedoya LM, Sanchez-Palomino S, Abad MJ, Bermejo P, Alcamim J (2001). Anti-HIV activity of medicinal plant extracts. J Ethnopharmacol 77:113-116.

Chapman J (2013). Hair loss: Getting to the root of the problem. Aust J Pharm 94(1118):70-74.

Choi ES, Kim JS, Kwon KH, Kim HS, Cho NP, Cho SD (2012a). Methanol extracs of Sanguisorba officinalis L. with cytotoxic activity against PC3 human prostate cancer cells. Mol Med Rep 6:670-674.

Choi J, Kim MY, Cha BC, Yoo ES, Yoon K, Lee J, Rho HS, Kim SY, Cho JY (2012b). ZYM-201 Sodium succinate ameliorates streptozotocin-induced hyperlipidemic conditions. Planta Medica 78:12-17.

Choi JY, Yoo ES, Cha BC, Park HJ, Rhee MH, Han YN (2006). The inhibitory effect of triterpenoid glycosides from Sanguisorba officinalis on tissue factor activity and the production of TNF-a. Planta Medica 72:1279-1284.

Cuccioloni M, Bonfili L, Mozzicafreddo M, Cecarini V (2012). Sanguisorba minor extract suppresses plasmin-mediated mechanisms of cancer cell migration. Biochim Biophys Acta 1820:1027-1034.

Douglas GB, Robertson AG, Chu ACP, Gordon IL (1994). Effect of plant age and severity of defolation on regrowth of sheep's burnet during substrate moisture depletion. Grass Forage Science 49:334-342.

Efthimiadou A, Karkanis A, Bilalis D, Katsenios N (2012). Cultivation of cow cockle (Vaccaria hispanica (Mill.) Rauschert): An industrial-medicinal weed. Ind Crops Prod 40:307-311.

Elgersma A, Søegaard K, Jensen SK (2013a). Herbagedry-matter production and forage quality of three legumes and four non-leguminous forbsgrown in single-species stands. Grass Forage Sci. doi: $10.1111 /$ gfs.12104.

Elgersma A, Søegaard K, Jensen SK (2013b). Fattyacids, $\alpha$ tocopherol, $\beta$-carotene, and lutein contents in forage legumes, forbs, and a grass-clover mixture. J Agr Food Chem 61:11913-11920.

Ferreira A, Proenca C, Serralheiro MLM, Araujo MEM (2006). The in vitro screening for acetylcholinesterase inhibition and antioxidant activity of medicinal plants from Portugal. J Ethnopharmacol 108:31-37.

Gatto MA, Ippolito A, Linsalata V, Cascarano NA, Nigro F, Vanadia S, Di Venere D (2011). Activity of extracts from wild edible herbs against postharvest fungal diseases of fruit and vegetables. Postharvest Biol Technol 61:72-82.

Goun EA, Petrichenko VM, Solodnikov SU, Suhinina TV, Kline MA, Cunningham G, Nguyen C, Miles H (2002). 
398

Anticancer and antithrobin activity of Russian plants. J Ethnopharmacol 8:337-342.

Holloway PS, Matheke GEM (2003). Seed germination of burnet Sanguisorba spp. Native Plants 4:95-99.

$\mathrm{Hu}$ J, Shi XD, Chen JG, Li CS (2012). Two new rhamnopyranosides of neolignans from Sanguisorba officinalis. J Asian Nat Prod Res 14:171-175.

Ji H-F, Li X-J, Zhang H-Y (2009). Natural products and drug discovery. Can thousands of years of ancient medical knowledge lead us to new and powerful drug combinations in the fight against cancer and dementia? EMPO Rep 10:194-200.

Karkanis A, Efthimadou A, Bilalis D (2011). Cultivation of milk thistle (Silybumm arianum L. Gaertn.), A Medicinal Weed. Ind Crops Prod 34:825-830.

Kaufmann D, Herrmann F, Wink M (2009). Extracts from traditional Chinese medical plants inhibit glycogen synthase kinase $3 \beta$ activity, a potential Alzheimer target. Z Phytother 30:V16.

Kim YH, Chung CB, Kim JG, Ko KI, Park SH, Kim J-H, Eom SY, Kim YS, Hwang YI, Kim KH (2008). Anti-wrinkle activity of ziyuglycoside I isolated from a Sanguisorba officinalis root extract and its application as a cosmeceutical ingredient. Biosci Biotechnol Biochem 72:303-311.

Kokubun T, Harborne JB, Eagles J (1994). 2',6'-dihydroxy-4' methoxyacetophenone, a phytoalexin from the roots of Sanguisorba minor. Phytochem 35:331-333.

Koukoura Z, Kyiazopoulos A, Karmiris I (2007). Herbaceous plant cover establishment on highway roadsides.Eco-and Ground Bio-Engineering: The use of vegetation to improve slope stability. Developments in Plant and Soil Sciences 103:387-391.

Lee NH, Lee MY, Lee JA, Jung DY, Seo CS, Kim JH, Shin HK (2010). Anti-asthmatic effect of Sanguisorba officinalis L. and potential role of heme oxygenase- 1 in an ovalbumininduced murine asthma model. Int J Mol Med 26:201-208.

Liu X, Cui Y, Yu Q, Yu B (2005). Triterenoids from Sanguisorba officinalis. Phytochem 66:1671-1679.

Liu X, Shi B, Yu B (2004). Four new dimerictriterpeneglucosides from Sanguisorba officinalis. Tetrahedron 60:11647-11654.

Lubbe A,Verpoorte R (2011). Cultivation of medicinal and aromatic plants for specialty industrial materials. Ind Crops Prod 34:785-801.

Menković N, Zdunić G, Šavikin K, Stanojković T, Juranić Z, Janković T (2007). Preliminary investigation of cytotoxic and antioxidant activity of some medicinal plants growing in Serbia and Montenegro.Planta Medica 73, p. 043.

Mondal S, Bandyopadhyay S, Ghosh MK, Mukhopadhyay S, Roy S, Mandal C (2012). Natural products: promising resources for cancer drug discovery. Anticancer Agents Med Chem 12(1):4975.

Moreira I, Madureira AM, Duarte A, Feijão MD, Correia AI, Teixeira G (2011). Sanguisorba hybrida: pharmacognostic and antimicrobialactivityevaluation. Planta Medica.77:P-L21.
Nelson RL, Peel MD, Ransom CV (2014). Small burnet response to spring and fall postemergenceherbicide applications. Weed Technol 28:68-175.

Ranfa A, Maurizi A, Romano B, Bodesmo M (2014). The importance of traditional uses and nutraceutical aspects of some edible wild plants in human nutrition: the case of Umbria (central Italy). Plant Biosyst 148(2):297-306

Redzic S (2010). Wild medicinal plants and their usage in traditional human therapy (Southern Bosnia and Herzegovina, W.Balkan). J Med Plant Res 4:1003-27.

Retta D, Dellacassa E, Villamil J, Suárez SA, Bandoni AL (2012). Marcela, a promising medicinal and aromatic plant from Latin America: A review. Ind Crops Prod 38:27-38.

Romojaro A, Sanchez-BelP, Serrano M, Pretel MT (2013). Wild edible plants as potential antioxidants in vegetables oils. J Chem ID 457902, 4 pages, doi:10.1155/2013/457902.

Sanchez-Bel P, Romojaro A, Egea I, Pretel MT (2014). Wild edible plants as potential antioxidant or nutritional supplements for beverages minimally processed. LWTFood Sci Technol. Article in Press.

Shin JA, Kim JS, Kwon KH, Nam JS, Jung JY, Cho NP, Cho SD (2012). Apoptotic effect of hot water extract of Sanguisorba officinalis L. in human oral cancer cells. Oncol Lett 4:489-494.

Sutton J (2007). Sanguisorba in cultivation. The Plantsman 6:78-83.

Tabet N (2006). Acetylcholinesterase inhibitors for Alzheimer's disease: anti-inflammatories in acetylcholine clothing. Age Ageing 35:336-338.

Vanzani P, Rossetto M, De Marco V, Sacchetti LE, Paoletti MG, Rigo A (2011). Wild Mediterranean plants as traditional food: a valuable source of antioxidants. J. Food Sci 76:46-51.

Wang Z, Loo WTY, Wang N, Chow LWC, Wang D, Han F, Zheng X, Chen JP (2012). Effect ofSanguisorba officinalis L. on breast cancer growth and angiogenesis. Expert Opin Ther Targets 16(S1):S79-S89.

Xia DZ, Yu XF, Zhu ZY, Zou ZD (2011). Antioxidant and antibacterial activity of six edible wild plants (Sonchus spp.) in China. Nat Prod Res: Former Nat Prod Lett25:18931901.

Yu T, Lee YJ, Yang HM, Han S, Kim JH, Lee Y, Kim C, Han MH, Kim MY, Lee J, Cho JY (2011). Inhibitory effect of Sanguisorba officinalis ethanol extracts on NO and PGE2 production is mediated by suppression of NF-Kb and AP-1 activation signaling cascade. J Ethnopharmacol 134:11-17. 